\title{
Seed dispersal of anemochoric Abies alba Mill.: lessons from seed tracking, seed trap experiments and the genetic parentage assignment of seedlings
}

\author{
Jarosław Paluch'\$\$, Marcin Zarek'1
}

Paluch J., Zarek M., 2020. Seed dispersal of anemochoric Abies alba Mill.: lessons from seed tracking, seed trap experiments and the genetic parentage assignment of seedlings. Ann. For. Res. 63(1): 19-38.

Abstract. Seed dispersal, an important process is estimated by different methods. In this study we compared seed shadows of the anemochoric species Abies alba Mill. obtained from (1) models derived from seed trapping data and inverse modelling, (2) ballistic models, based on wind speed at canopy height and an exponential wind profile and (3) empirical models parameterised from seed-tracking data. In addition, we checked whether the empirical model coupled with multiannual wind characteristics provides a dispersal pattern concordant with the gene shadow obtained from parentage assignment between seedlings and overstorey trees. The seed trap and seed-tracking experiments were conducted in 2013 and 2015 with contrasting wind conditions in five study plots located in the Krynica Forest Experimental Station in southern Poland, while the genetic data originated from 16 mature stands with dominant $A$. alba. The study revealed that the distances reached by single seeds strongly vary at the same wind speed at canopy height. The ballistic model overestimated the flight distances of $A$. alba seeds and similarly, the empirical model calibrated on data that disregarded seeds trapped in the crowns of neighbouring conifer trees predicted longer flight distances than those derived from the seed trap experiments. The gene shadow obtained from the parentage analysis suggests dispersal patterns concordant with those anticipated by the empirical model based on the seed-tracking experiments, with a possible shift towards an increased proportion of seeds landing close to the source. We concluded that in dense canopies collisions with canopy elements during seed flight and secondary dispersion of seeds trapped in the canopy zone may considerably shorten the travel distances of $A$. alba seeds.

Keywords: wind dispersal, seed shadow, seed-tracking, gene shadow, natural regeneration, inverse modelling

Authors. ${ }^{1}$ University of Agriculture, Al. 29 Listopada 46, 31-425 Cracow, Poland. § Corresponding author: Jarosław Paluch (jaroslaw.paluch@urk.edu.pl)

Manuscript received December 10, 2019; revised February 5, 2020; accepted February 17, 2020; online first March $2^{\text {nd }}, 2020$. 


\section{Introduction}

Seed dispersal is a decisive factor in colonisation ability and hence determines the response of vegetation to climatic changes, natural disturbances and anthropogenic impacts (Higgins \& Richardson 1999, Bullock et al. 2012). The production and dispersal of seeds co-determine species-specific regeneration strategies and play a crucial role in maintaining the species diversity of plant communities (Snyder \& Chesson 2004). Seed dispersal is of vital importance to mechanisms influencing biological diversity. It affects gene flow and the spatial genetic structure of populations (Vornam et al. 2004, Sagnard et al. 2011).

Seed dispersal may exhibit considerable spatial and temporal variation. This process is governed by many different factors and processes: inter-annual and inter-specimen variation in seed production (Turner et al. 2007, Paluch 2011), fluctuation in the population density of seed predators (Horvitz \& Schemske 1994, Skrzypczyńska et al. 2001), seed abscission conditions (Greene 2005, Bohrer et al. 2008), the characteristics and behaviour of dispersing agents (Higgins et al. 2003, Westcott et al. 2005), the heterogeneity of the landscape (Bullock et al. 2002), the occurrence of secondary seed dispersal (Greene \& Johnson 1997) and local determinants such as smallscale terrain topography or the characteristics of the vegetation layer (Bullock et al. 2003, Bullock \& Moy 2004). The variability of the interacting factors and multi-stage character of the dispersal process inevitably makes its modelling extremely complex and challenging.

Several methods are used to construct dispersal models for anemochoric species. The traditional approach relies on measurements of the distance travelled by seeds released from a predetermined height (Kohlermann 1950, Grivet et al. 2005). When tests are conducted in different wind conditions, the results may be generalised and applied for any wind speeds. To facilitate seed tracking, enrichment of their generative organs with stable isotopes has been proposed (Carlo et al. 2009). Seed dispersal patterns may also be reconstructed on the basis of seed trapping experiments and the application of an inverse modelling approach (Greene \& Calogeropoulos 2002). This method relies on numeric calculations of the likelihood of obtaining the observed seed dispersion pattern using a model that specifies the seed shadows of the mapped seed sources. The results of seed trapping experiments are valid only for the exact conditions under which the experiment was performed. Consequently, the resulting models lack generality as the variable behaviour of the dispersal factors are ignored. Moreover, model fitting becomes problematic if long-distance dispersal (with a low probability of seed landing events) is of pivotal importance (Bullock \& Clarke 2000, Nathan et al. 2003, Pielaat et al. 2006). The results of modelling strongly depend on the seed trapping layout (Skarpaas et al. 2005), the selection of a sufficient panel of dispersal kernel families (Green et al. 2004, Bullock et al. 2006) and the inclusion of appropriate directional parameters (Sánchez et al. 2011).

More refined models are directly based on wind flow dynamics and include equations for the effect of gravity and drag forces exerted on a vertically falling particle (Schurr et al. 2005, Kuparinen 2006, Nathan et al. 2011). Because of their wide applicability, the development of such mechanistic models would be beneficial, and substantial efforts have been made to characterize wind fluxes in forest canopies and their effect on the trajectories of falling seeds. To date, most simple models of this type have been based solely on the mean horizontal wind speed and assume the seed falls at a constant velocity in still air (Augspurger 1986, Nathan et al. 2002). Although the models frequently provide acceptable descriptions of short-distance dispersal, they are totally inadequate for predicting long-distance dispersal as this is strongly influenced by uplifting events (Tack- 
enberg 2003), turbulence arising from warming of the ground surface (Kuparinen et al. 2009), terrain orography, canopy structure and the relationship between the release height and the canopy height (Bohrer et al. 2008). What is critical for the relevance of mechanistic models is the seed release behaviour since seeds can be abscised in a very narrow range of specific conditions, and dispersal and release processes can frequently be triggered by different and species-specific factors (Schippers \& Jongejans 2005). It follows that mechanistic models are not easy to formulate because of the significant number of variables that need to be considered. Moreover, much empirical work is still needed to assess their reliability and to identify the parameters that need detailed measurement versus those that may be safely estimated (Nathan et al. 2011). However, once validated, mechanistic models may be applied in a wide range of conditions without substantial loss of accuracy.

Seed dispersal may also be investigated using parentage analyses based on genetic markers determined in the populations of parent trees and seeds or young seedlings (Raybould et al. 2002, Burczyk et al. 2006, Jones et al. 2010). In such analyses the maternal DNA from dispersed fruits or seed coats is the most relevant (Hamrick \& Trapnell 2011). If biparental genetic material is inherited, there is the problem of determining the egg/pollen donor in monoecious species (Meagher \& Thompson 1986). Another common problem is that only a proportion of the seeds may be assigned to unique potential maternal trees because of the insufficient exclusion power of genetic markers (Moran \& Clark 2011) or seed and pollen immigration from individuals residing outside the study population (Oddou-Muratorio \& Klein 2008, Chybicki \& Burczyk 2010). Finally, as with seed trap experiments, the results of genetic parentage assignment are representative only for the conditions in which the analysis was carried out, and thus the generality of the seed dispersal models constructed in this way may be very limited.

All the approaches described above have specific shortcomings that limit their reliability and/or the generality of the estimated dispersal patterns. A comparison of the models obtained by the various approaches will give a better understanding of their limitations and should enable more realistic estimates. The objective of this study was to compare seed shadows of the anemochoric species Abies alba Mill. obtained from (1) models derived from seed trapping data and inverse modelling, (2) ballistic models based on wind speed at canopy height and (3) empirical models parameterised from seed-tracking data. In addition, we checked whether the empirical model coupled with multiannual wind characteristics provides a dispersal pattern concordant with the gene shadow obtained from parentage assignment between seedlings and overstorey trees. Anemochoric Abies alba Mill. was selected for this study as it produces seeds that are sufficiently large to be tracked in flight, and the data on seed flight distances can be used to construct empirical models. Moreover, in forests containing $A$. alba, the species is frequently naturally regenerated, and an understanding of its dispersal biology is particularly useful for practical applications.

\section{Materials and methods}

\section{Study species and region}

Abies alba Mill. is a diploid monoecious tree producing wind-dispersed seeds. Within a decade, $A$. alba can be expected to produce two full masts and two partial masts with seed production between 40 and $70 \%$ of that in full mast (Rohmeder 1972). Trees of this species flourish at the end of April and beginning of May. Among the conifers, A. alba has very heavy pollen of a weight of ca. $251.1 \times 10^{-6} \mathrm{~g}$ per 1,000 grains and a sedimentation velocity of ca. $0.12 \mathrm{~m} \mathrm{~s}^{-1}$ (Eisenhut 1961). The winged 
seeds are relatively heavy (50-55 g per 1,000 dried seeds) (Suszka 1983, Schütt 1991) and fall most intensively in October.

The field work was conducted in 2013 and 2015 in five study plots located in the Forest Experimental Station in Krynica (20.9538 E, $49.4511 \mathrm{~N}$ ), southern Poland. The plots were established at an altitude of 650 to $750 \mathrm{~m}$ asl on even south-western slopes with an inclination ranging between 5 and $15 \%$. In this region the growth period (with a mean daily temperature above $5^{\circ} \mathrm{C}$ ) is ca. 180 days per annum. The average annual temperature is $6^{\circ} \mathrm{C}$, and the annual precipitation is $950 \mathrm{~mm}, 60 \%$ of which occurs between May and October (Paszyński $\&$ Niedźwiedź 1999). Advection of air masses from the western quadrant prevails on $46 \%$ of the days, and from October to December the proportion of strong winds from the south and south-west directions usually increases. During this period the average wind speed is between $1.5 \mathrm{~m} \mathrm{~s}^{-1}$ in the shielded valleys and $5 \mathrm{~m}$ $\mathrm{s}^{-1}$ in the summit areas (Trepińska \& Kowanetz 2000). According to data from a meteorological station located between 4 and $10 \mathrm{~km}$ from the study plots at an altitude of $740 \mathrm{~m}$ asl, wind conditions from October to December of 2013 and 2015 strongly varied: the mean wind speed was 3.7 and $1.5 \mathrm{~m} \mathrm{~s}^{-1}$, accounting for $180 \%$ and $70 \%$ of the long-term average value $(2.0$ $\mathrm{m} \mathrm{s}^{-1}$ ), and the proportion of days with a mean wind speed above $5.0 \mathrm{~m} \mathrm{~s}^{-1}$ was $25 \%$ and $1 \%$, respectively. The five study plots are located in one-storeyed stands of an age of 70 to $90 \mathrm{yrs}$. consisting of Norway spruce Picea abies (L.) H. Karst. with a small admixture of $A$. alba. (plots I and V) or $A$. alba (plots II-IV). The stand basal areas varied between 24 and $40 \mathrm{~m}^{2}$ $\mathrm{ha}^{-1}$. Detailed characteristics of the study plots are given in Table 1.

\section{Models based on seed trap experiments}

In 2013 on two study plots (I-II) and in 2015 on five study plots (I-V), 20 seed traps were placed horizontally at ground level in square 5 $\times 5 \mathrm{~m}$ lattices (Table 1). The seed traps had a catchment area of $0.25 \mathrm{~m}^{2}$, a base made from a dark synthetic water-permeable fabric and 15 $\mathrm{cm}$ high brims formed by strong fibreboard. The traps were placed in the second half of September before seed fall. In each sample plot we recorded the diameter at breast height of all live trees $(\geq 7.0 \mathrm{~cm}$ in diameter), the heights of a portion of the trees and the stem coordinates (exact to $0.1 \mathrm{~m}$ using a compass and ultrasonic distance meter) of all seed-bearing A. alba trees (maternal trees). The size of the sample plots ensured that all maternal trees at least $30 \mathrm{~m}$ from the outermost seed traps

Table 1 Sampling design of the seed trap experiment and basic characteristics of the study plots

\begin{tabular}{|c|c|c|c|c|c|c|c|c|c|}
\hline Plot & $\begin{array}{l}\text { Species } \\
\text { composition } \\
(\% \text { in BA })\end{array}$ & & $\begin{array}{l}\text { Stand } \\
\text { basal } \\
\text { area } \\
(\mathrm{BA}) \\
\left(\mathrm{m}^{2} \mathrm{ha}^{-1}\right)\end{array}$ & $\begin{array}{l}\text { Top } \\
\text { height } \\
\text { (m) }\end{array}$ & $\begin{array}{l}\text { Exposition } \\
\text { (slope in \%) }\end{array}$ & $\begin{array}{l}\text { Attenuation } \\
\text { coefficient } \alpha\end{array}$ & $\begin{array}{l}\text { Seed } \\
\text { fall } \\
\text { season }\end{array}$ & $\begin{array}{l}\text { Number } \\
\text { of trees } \\
\text { with } \\
\text { cones }\left(\mathrm{ha}^{-1}\right)\end{array}$ & $\begin{array}{l}\text { Number } \\
\text { of cones } \\
\text { per tree } \\
\text { (mean } \\
\text { and SD) }\end{array}$ \\
\hline I & $\begin{array}{l}\text { Picea abies } \\
\text { Abies alba }\end{array}$ & $\begin{array}{l}90 \\
10 \\
\end{array}$ & 40 & 28 & West (13) & 2.84 & $\begin{array}{l}2013 \\
2015 \\
\end{array}$ & $\begin{array}{l}18 \\
33 \\
\end{array}$ & $\begin{array}{l}176.7(107.7) \\
58.9(45.2) \\
\end{array}$ \\
\hline II & Abies alba & 100 & 34 & 30 & $\begin{array}{l}\text { South-west } \\
\text { (5) }\end{array}$ & 2.33 & $\begin{array}{l}2013 \\
2015\end{array}$ & $\begin{array}{l}44 \\
18\end{array}$ & $\begin{array}{l}63.7(48.8) \\
206.0(119.0)\end{array}$ \\
\hline III & Abies alba & 100 & 39 & 29 & $\begin{array}{l}\text { South-west } \\
(15)\end{array}$ & 2.71 & 2015 & 44 & $46.0(29.4)$ \\
\hline IV & Abies alba & 100 & 27 & 28 & $\begin{array}{l}\text { South-west } \\
\text { (15) }\end{array}$ & 1.55 & 2015 & 74 & $74.2(31.2)$ \\
\hline V & $\begin{array}{l}\text { Picea abies } \\
\text { Abies alba }\end{array}$ & $\begin{array}{l}90 \\
10\end{array}$ & 24 & 29 & $\begin{array}{l}\text { South-west } \\
\text { (5) }\end{array}$ & 0.92 & 2015 & 12 & $150.1(113.0)$ \\
\hline
\end{tabular}


were mapped. Before the cones totally disintegrated, the crowns of the maternal trees were photographed from the tops of the neighbouring trees growing in the uphill direction using a Canon digital camera with an EF 100-400 $\mathrm{mm}$ f/4.5-5.6L IS USM lens. In addition, on each sample plot the cones on 3-5 maternal trees were directly counted, and the numbers were compared with estimates derived from the photographs. As the results were similar, with differences usually between 2 and $8 \%$, it was assumed that the figures attained from the analysis of the photographs increased by an average error value of $3.4 \%$ provided reliable estimates of the number of cones on any specific tree. During frequent visits to the sample plots, including visits between late afternoon and nightfall, no evidence of increased seed predator activity was observed. The seeds were collected from the traps in the last 10 days of April and counted in the laboratory. In addition, to gain a deeper insight into the pattern of secondary dispersal of seeds trapped in the tree crowns, in 2015 the seeds on plots III and IV were collected in the first 10 days of December and in April.

An inverse modelling technique was used to estimate the probability that a seed would fall at a given distance from the maternal tree. This method accounts for the overlap of seed shadows by comparing the seed counts obtained at the trapping locations to the expected number of seeds computed from the basic seed dispersal kernel and the individual adult fecundities. For coherence with models based on wind characteristics, an inverse Gaussian (Wald) distribution of dispersal distances was used, and the fitted kernel was:

$$
p(r)=\operatorname{Nexp}\left[-\frac{\lambda(r-\mu)^{2}}{2 \mu^{2} r}\right],
$$

where $\mu$ is the location parameter, $\lambda$ is the scale parameter, $N=\sqrt{\frac{\lambda}{2 \pi^{3} r^{5}}}$ is the normalising factor to satisfy $2 \pi \int_{0}^{\infty} f(r) r d r$. The inverse Gaussian kernel highlights turbulent updrafts and exhibits a power-law behaviour with un-bounded variance. Moreover, its location parameter is directly linked with a height-averaged (effective) wind speed and the Wald and ballistic predictions may be directly compared (Nathan et al. 2011). Because the research plots were located on slopes, a correction accounting for the asymmetry of the seed shadows in the uphill and downhill directions was included:

$$
\hat{r}=r+\frac{\Delta z r}{H_{s}}
$$

where $\hat{r}$ is the corrected distance, $r$ is the horizontal distance between the tree and the trap, $\Delta z$ is the difference between the $z$-coordinate of the trap and tree base and $H_{s}$ is the average height from which the seed was released. The seed release heights were determined as the tree heights minus $2 \mathrm{~m}$, with tree heights being calculated from diameter-height relationships. Based on the counting of seeds in $50 \mathrm{~A}$. alba cones collected in 2013 from 10 trees in the studied stands, the mean number of seeds was estimated at 250 per cone.

Because asymmetric seed shadows depending on prevailing wind directions were expected, this variable was included by the incorporation of a von Mises function into the dispersal model:

$$
g(\varphi)=\frac{\exp [\mathrm{k} \cos (\varphi-\mathrm{A})]}{2 \pi J_{0}(k)}
$$

where $\phi$ is the azimuth of the fallen seed measured from the maternal tree, $A$ is a measure of location (here the dominant wind direction), $k$ is a measure of concentration represented by a real number and $J_{0}(k)$ is the modified Bessel function of order 0 . For $k=0$ the value of $g(\phi)$ is constant, meaning the isotropic distribution of seeds around the maternal tree; for $k>0$ the probability of falling seeds increases leeward from the source and decreases windward. In this approach, the parameters $A$ and $k$ were treated as constants and were derived from the meteorological station at the Forest Experimental Station in Krynica for the seed fall 
seasons between 1 October and 30 December. Because the resulting distributions of seed fall directions had two maxima in 2013 and 2015, two superimposed von Misses functions were used with the following parameters: for 2013 $A_{1}=300, k_{1}=2.3, A_{2}=106, k_{2}=2.6$ and for $2015 A_{1}=343, k_{1}=3.7, A_{2}=176, k_{2}=3.6$.

For a given set of parameters $\mu$ and $\lambda$, the number of seeds $n_{i}$ in the $i^{\text {th }}$ trap of a catch area of $0.25 \mathrm{~m}^{2}$ was calculated as

$n_{i}=\sum 0.25 S_{j} p\left(\hat{r}_{i j}\right) g\left(\varphi_{i j}\right)+\bar{n}\left(1-2 \pi \int_{0}^{b_{i}} p(r) r d r\right)$

where the summation is over all trees within the radius $b_{i}$ from the $i^{\text {th }}$ trap, $b_{i}$ is the horizontal distance of the $i$ th trap to the nearest borderline of the plot $\left(b_{i}>30 \mathrm{~m}\right), S_{j}$ is the number of seeds produced by the $j$ th tree, $\hat{r}_{i j}$ is the corrected distance between the $i$ th trap and the $j$ th tree, $\bar{n}$ denotes the empirical mean of the seed counts in all the traps and other symbols were as defined above. The second term in the formulation is a correction factor for seeds immigrating from beyond the sample plot based on the simplified assumption that $A$. alba trees bearing seeds occur with a constant density. The model parameters were obtained from 500 bootstrapped maximum likelihood estimates with the Poisson likelihood assumed. The deviance of the fitted model against the Poisson model, in which the observed seed count equals the sample mean, was then compared to a chi-squared distribution. The goodness of fit was expressed by McFadden's $R^{2}$ (likelihood ratio index) scaled to attain a value of 1 for the fully saturated model in which the predicted and observed seed counts were equal.

\section{Ballistic model}

In the ballistic model the distances travelled by $A$. alba seeds were directly obtained from an exponential wind profile determined in the central part of each study plot. In the model the wind speed at height $h, v_{h}$, was derived from the horizontal wind speed at the canopy height
$v_{H}$ and an attenuation coefficient $\alpha$ dependent on the canopy density:

$$
v_{h}=v_{H} \exp \left[\alpha\left(\frac{h}{H}-1\right)\right]
$$

The attenuation coefficient tends to increase with increasing canopy density, and the decline in horizontal windspeed is most rapid in forests of high foliage and stem density (Kaimal and Finnigan 1994). The empirical values of the coefficient $\alpha$ were determined based on simultaneous measurements of the wind speed by anemometers (S-WSET-A connected to Micro Station H21-002, Onset, USA, frequency $1 \mathrm{~Hz}$ ) installed at the canopy height $H$ and $h=0.1 H, 0.2 H, 0.4 H, 0.6 H$ and $0.8 H$ in the central part of each plot. The measurements were repeated three times at different wind conditions and resulted in the following $\alpha$ values for the five study plots: $2.84,2.71$, 2.33, 1.55, 0.92 (Fig. 1). Knowing the wind speed, the distance $r$ reached by the seed was computed by integration with respect to time $t$

$$
r=\int v_{h(t)} d t
$$

where the momentary height of the seed above the ground $h(t)=H_{s}-v_{0} t, H_{s}$ is the release height, and $v_{0}$ denotes falling velocity of the seeds. The value was empirically derived

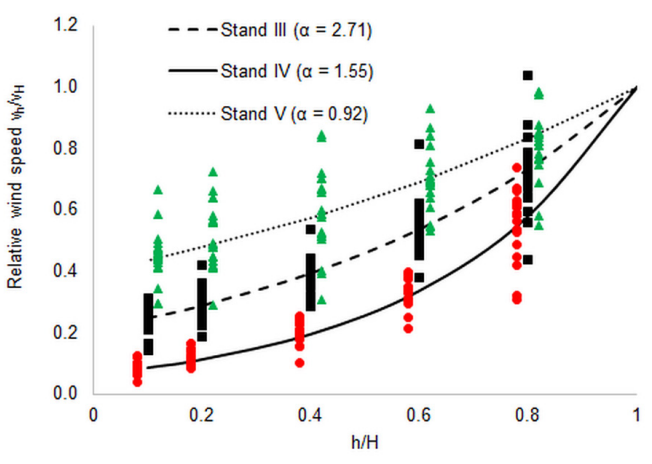

Figure 1

Exponential wind-profiles on plots III-V determined on the basis of simultaneous measurements of wind speed at canopy height $H$ and relative heights $h / H$ (mean values for intervals of $30 \mathrm{~s}$ ) 
based on recording the flight time of 50 seeds in still air (mean $\left.\pm \mathrm{SD}=1.30 \pm 0.16 \mathrm{~m} \mathrm{~s}^{-1}\right)$. The falling velocity calculated in this study approximated the results reported by Kohlermann (1950) $\left(1.25 \mathrm{~m} \mathrm{~s}^{-1}\right)$.

\section{Empirical model based on seed tracking experiments}

\section{Seed release module}

The seed release model was constructed firstly based on the direct observation of the release of seeds from cones in experimental conditions (the seed release experiment) and secondly on monitoring the intensity of seed fall in forest stands in different weather conditions. To carry out the seed release experiment, in late September 2013 a 3 m length containing 15 cones was cut from the top of a mature $A$. alba tree shortly before the seeds were released. The top was placed in the vertical position on the ground in a container filled with water and fenced with a wire mesh to prevent uncontrolled seed migration. The seeds falling onto the ground and the seeds released from the cones but trapped on shoots between the needles were separately counted each day until no seeds remained. During the observation period the wind speed at the tree top was registered by an anemometer (S-WSET-A, Onset, USA) connected to a logger (Micro Station H21-002, Onset, USA). In the 2013 and 2015 seasons, the intensity of $A$. alba seed fall was also monitored in two $A$. alba stands (age ca. 90-110 years, basal area 32 and $38 \mathrm{~m}^{2} \mathrm{ha}^{-1}$, respectively). In each of the stands, 10 seed traps with a catchment area of $0.25 \mathrm{~m}^{2}$ were placed in a line every $10 \mathrm{~m}$. The fallen seeds were counted ca. every 5 days and whenever weather conditions changed until permanent snow cover occurred and again the following spring when the snow melted. During the observation period the wind speed at tree top height was registered by an anemometer connected to a logger as described above. The model of seed release was based on the re- lationship between the average wind speed per $24 \mathrm{~h}$ and the proportion of fallen seeds relative to the total number of seeds remaining in the crown zone. This could easily be calculated at the end of the seed fall period by the backward summation of the seeds fallen in the control periods. Because the results from the seed release experiments and the observations of seed fall intensity in forest conditions corresponded, they were combined, and a power function was fitted to produce a model of $A$. alba seed release in relation to the average wind speed per $24 \mathrm{~h}$.

\section{Seed dispersal module}

To obtain the seed dispersal model, A. alba seeds were dropped from the tops of $A$. alba trees growing within the five study plots. In each site the experiments were conducted two or three times in October and covered a wind speed range between 1 and $7 \mathrm{~m} \mathrm{~s}^{-1}$ (at the tree tops). The flight trajectories and final distances reached by the seeds were tracked by observers, one at tree top height and, depending on the wind speed, one or two on the ground. In each single experiment the seeds were tracked until a sample of at least 50 seeds was obtained. For each site the relationship between the mean wind speed at canopy height $H$ during seed flight and the relative distance travelled (i.e. the distance from the source tree to the final position of the seed on the ground divided by $H$ ) was generalized using ordinary linear regression and then compared with the distances predicted by the ballistic model. In the estimation procedure only complete records for the seeds that were successfully tracked by observers and reached the ground were used. Seeds retained in the crowns of the maternal trees or their neighbours were excluded (depending on sample plots and wind conditions, between 11 and $96 \%$ of the seeds released in a single series). In addition, at wind speeds above $5 \mathrm{~m} \mathrm{~s}^{-1}$, a considerable proportion of the released seeds could not be tracked by the 
observers because of their rapid movement. Therefore, to reduce any bias caused by the omission of seeds that could have potentially achieved the longest flight distances, the analysis was restricted to wind speeds below $5 \mathrm{~m}$ $\mathrm{s}^{-1}$. Similar to data for open space conditions provided by Kohlermann (1950), the analysis of the data collected in this study in forest interiors indicates that ordinary linear regression gives a good approximation of the relationship between wind speed and the distance travelled by the seeds and that extrapolation of the regression models beyond the wind speed threshold used in the calibration is acceptable.

\section{Generalized empirical model}

To enable modelling of flight distances of $A$. alba seeds at different wind speeds in canopies of a predefined attenuation coefficient $\alpha$, the dispersal module was coupled with the seed release module (Fig. 2), and the empirical relationships between wind speed and flight distances established in the study plots were generalized in the form of an inverse Gaussian (Wald) distribution. The distribution parameters and are related to species and environment characteristics as follows (Nathan et al. 2011):

$$
\begin{aligned}
& \mu=\frac{H_{r} \bar{v}}{v_{0}}, \\
& \lambda=\left(\frac{H_{r}}{\sigma}\right)^{2}
\end{aligned}
$$

where $H_{r}$ and $v_{0}$ were defined above, $v_{0}$ is the hourly mean horizontal wind velocity between $H_{r}$ and the ground calculated from the exponential wind-profiles, and $\sigma$ is a turbulent flow parameter that reflects wind variation due to vegetation structure. This parameter was fitted to the dispersal data and linked with the attenuation coefficient by the empirical relationship $\sigma=-0.124 \alpha+0.474$.

The generalized empirical model was applied to simulate seed shadows (i.e. distributions of the distances travelled by seeds) for data on wind speed in 2013 and 2015 and then compared with the seed shadows derived from the seed trap experiments. The meteorological input data for the seed fall period between 1 October and 31 December 2015 were obtained from the meteorological station in the Forest Experimental Station in Krynica and then, based on several simultaneous measurements, adjusted to the local conditions on the study plots.

\section{Parentage assignment}

For this analysis genetic data previously collected from 16 mature stands with dominant A. alba were used. Like the sample plots in which the seed trap and seed-tracking experiments were carried out, these stands were located in the lower mountain belt of the Western Carpathians at an altitude of 600-800 m asl on southern, south-western or north-western slopes. The stand age varied between 70 and 110 years, top height between 28 and $33 \mathrm{~m}$ and basal area between 30 and $40 \mathrm{~m}^{2} \mathrm{ha}^{-1}$. The stands were characterized by relative homogeneity of site conditions and stand structure, a lack of intensive silvicultural cuttings or natural disturbances during the last two decades and the occurrence of a naturally established A. alba seedling bank.

In the central zone of every stand, a circular plot of a radius of $35 \mathrm{~m}$ was established, and 30 adult $A$. alba trees from the overstorey were marked. Then, at a radius of between 1 and 5 $\mathrm{m}$ from each of the 30 adult trees, one $A$. alba seedling aged between 5 and 15 years was randomly selected (30 seedlings per stand). The coordinates of the adult trees and the seedlings were determined to $0.1 \mathrm{~m}$ accuracy. In June 2016 from every adult tree and every seedling, a sample of current-year needles was taken, secured in plastic bags, marked and transported to the laboratory. Five nuclear simple sequence repeat (nSSR) markers (SF239, SFb5, SFb4, SF333, SF78 - Cremer et al. 2006) were determined for each individual. Details of the genetic analyses are given in Paluch et al. (2019). 


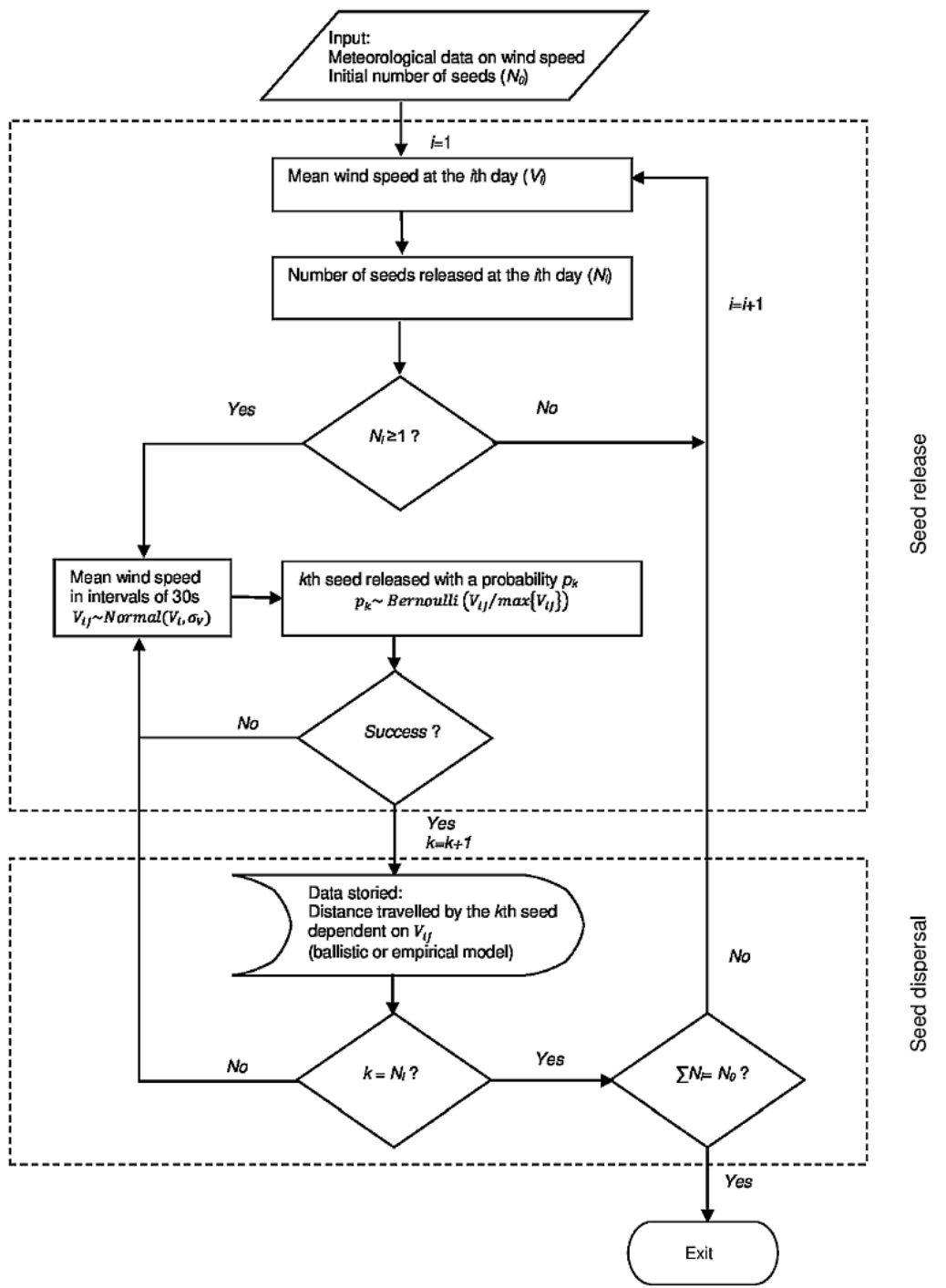

Figure 2 Scheme of ballistic and empirical models of $A$. alba seed dispersal

Explanation: mean and variation in wind speed at canopy height was estimated from wind speeds recorded at the meteorological station and reference measurements conducted in the study plots. The Ni value was calculated as described in the seed release module section. The flight distances were determined from the exponential wind profiles in the ballistic model or derived as a random variable from a locally fitted inverse Gaussian (Wald) distribution in the empirical model.

As a result of the nSSR analysis, genotypic data for 30 mature trees and 30 seedlings were obtained for each of the 16 stands. Then, Cervus 3.0.7 software was used for assignment of parentage based on LOD scores, i.e. the natural log of the likelihood that the candidate parent is the true parent divided by the likelihood that the candidate parent is not the true parent (Kalinowski et al. 2007). For each seedling tested, parentage was assigned to the 
most likely candidate parents with a pre-determined confidence level of $95 \%$ and, alternatively, a relaxed confidence level of $80 \%$. Then, for each stand the proportion of positive assignments in the total number of checked parent-seedling distances was determined in 5-m distance classes, and the inverse Gaussian distribution was used to model the averaged proportions across distance. The effect of different fecundity was omitted because all the sampled adult trees originated from the social class of dominant individuals and had similar diameters. In accordance with the results from the seed-tracking experiments, we assumed that for the maximal distance of analysis (70 $\mathrm{m})$, the cumulated probability of finding a parent tree is 0.85 . The model parameters were obtained from 500 bootstrapped maximum likelihood estimates with the Poisson likelihood assumed.

The results from the parentage assignments were compared with the predictions of the empirical model applied to simulate multiannual (cumulative) seed shadows. In this case the settings were as follows: simulation period of 20 years, wind conditions derived as a random sample from three-month sequences (between 1 October and 30 December) recorded for the period 2000-2015 at five meteorological stations representative for the study region (mean and SD of wind speed $=2.35 \pm 0.51 \mathrm{~m}$ $\mathrm{s}^{-1}$ ) and seed production per year represented by a random variable with properties based on data by Rohmeder (1972), i.e. within a decade, two full masts (seed production $>70 \%$ ), two partial masts with seed production between 40 and $70 \%$, and two partial masts with seed production between 10 and $39 \%$ are expected. The basic seed production was set at 20,000 seeds, which corresponds to the average number of cones found on trees in the seed trap experiments ( 80 cones per tree). The proportion of seeds that fell at given distance intervals from their source was estimated by the mean of 1,000 runs of the empirical model. To cover the range of stand densities in which the data for parentage analysis were collected (basal 28 areas between 30 and $\left.40 \mathrm{~m}^{2} \mathrm{ha}^{-1}\right)$, the models were run for the attenuation coefficient $\alpha=2$ and $\alpha=2.8$.

The calculations were programmed using Statistica 12 software (StatSoft, Inc. USA) and Visual Basic for Applications 7.1 (Microsoft, Inc. USA).

\section{Results}

\section{Models based on seed trap experiments}

The dispersal models based on data from the seed trap experiments are displayed in Fig. 3 and parameters of the corresponding distributions are listed in Table 2. McFadden's $R^{2}$ coefficients for the models including entire seed fall season varied in a wide range between 0.11 and 0.50 , indicating diverse levels of model fit. In stands I-III with relatively closed canopies, the median dispersal distance (i.e. distance below which $50 \%$ of the seeds fell) was estimated at between 10.8 and $14.3 \mathrm{~m}$. In 2013 on plot II this value amounted to $29.4 \mathrm{~m}$. Nonetheless, in this case the correlation between the empirical and modelled seed counts was weak and indicated poor model fit. Higher median dispersal distances (16.6 and $25.5 \mathrm{~m}$ ) were obtained in low-density $A$. alba stands on plots IV and $\mathrm{V}$. The distributions of distances travelled by the seeds in winter (secondary dispersal between December and April) clearly differed from the distributions for primary dispersal in autumn (Fig. 3). The secondary dispersal resulted in a strong concentration of seeds close to the mother trees, with the median distance estimated at 3.7 and $9.0 \mathrm{~m}$, respectively. The majority of seeds collected between December and April (73\%) had either lost their wings entirely or had damaged wings. In the case of the seeds collected between September and November, this proportion was significantly lower $(27 \%)$. 

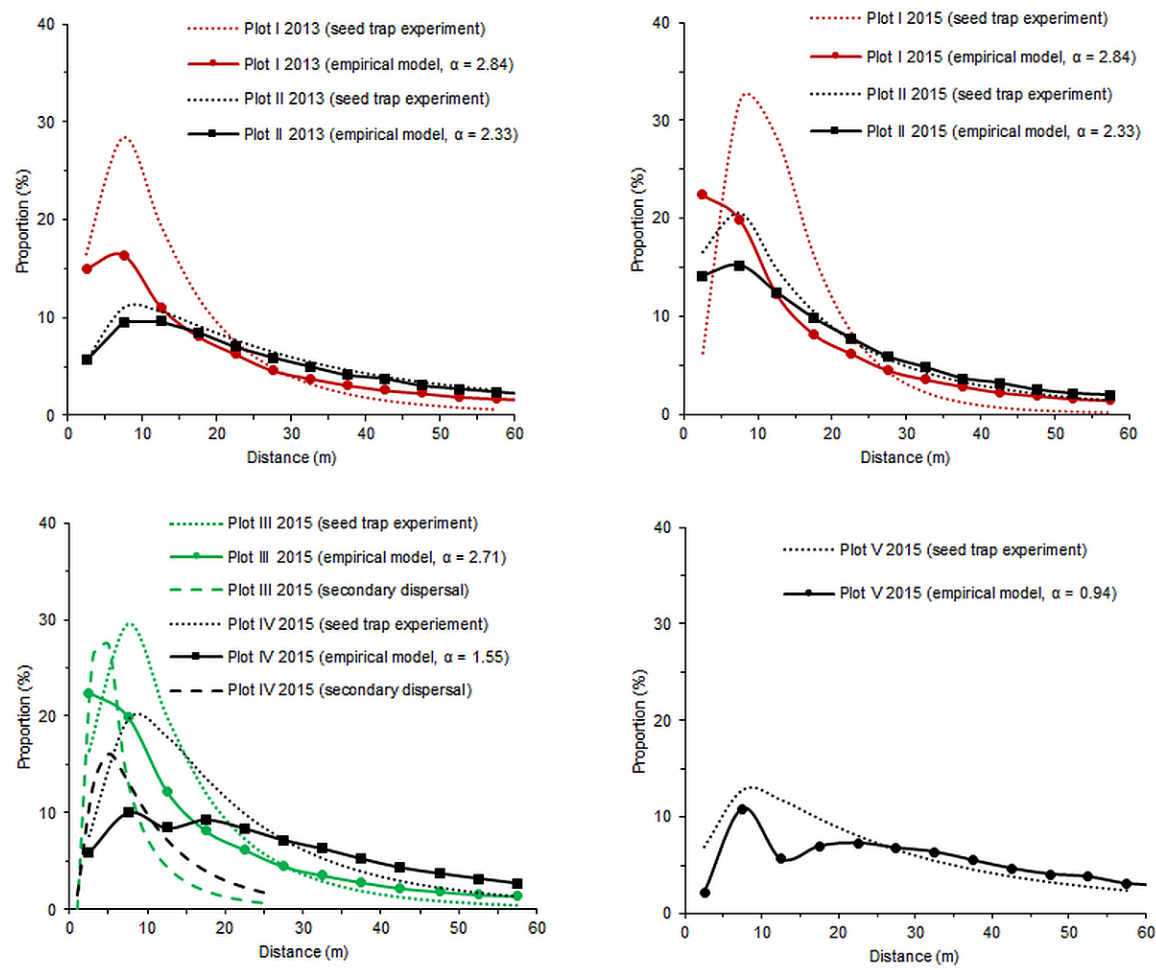

Figure 3 Comparison of seed shadows obtained from seed trap experiments carried out in 2013 and 2015 and simulated by using the empirical model of seed dispersal

\begin{tabular}{|c|c|c|c|c|c|c|c|}
\hline Plot & Year & $\mu \pm \mathrm{SE}$ & $\lambda \pm \mathrm{SE}$ & SEE & $\begin{array}{l}\text { Corre- } \\
\text { lation } \\
\text { coeff. }\end{array}$ & $\begin{array}{l}\text { Pseudo } \\
\mathrm{R}^{2}\end{array}$ & $\begin{array}{l}\text { Deviance } \\
\text { (sign. level) }\end{array}$ \\
\hline \multirow[t]{2}{*}{ I } & 2013 & $\begin{array}{r}15.90 \\
(0.50)\end{array}$ & $\begin{array}{r}17.73 \\
(2.53)\end{array}$ & 11.1 & 0.78 & 0.39 & $\begin{array}{r}108.9 \\
(0.001)\end{array}$ \\
\hline & 2015 & $\begin{array}{r}13.94 \\
(0.64) \\
\end{array}$ & $\begin{array}{l}39.41 \\
(2.88) \\
\end{array}$ & 7.2 & 0.60 & 0.15 & $\begin{array}{r}40.9 \\
(0.001) \\
\end{array}$ \\
\hline \multirow[t]{2}{*}{ II } & 2013 & $\begin{array}{l}71.37 \\
(1.05)\end{array}$ & $\begin{array}{l}25.69 \\
(2.08)\end{array}$ & 12.6 & 0.30 & 0.11 & $\begin{array}{r}22.8 \\
(0.001)\end{array}$ \\
\hline & 2015 & $\begin{array}{l}29.05 \\
(0.76)\end{array}$ & $\begin{array}{l}13.29 \\
(1.11)\end{array}$ & 12.0 & 0.92 & 0.50 & $\begin{array}{r}181.0 \\
(0.001)\end{array}$ \\
\hline III & 2015 & $\begin{array}{l}14.99 \\
(0.88)\end{array}$ & $\begin{array}{l}18.50 \\
(2.11)\end{array}$ & 5.6 & 0.83 & 0.38 & $\begin{array}{r}16.0 \\
(0.001)\end{array}$ \\
\hline $\mathrm{III}^{2}$ & 2015 & $\begin{array}{r}3.41 \\
(0.21)\end{array}$ & $\begin{array}{r}4.21 \\
(0.17)\end{array}$ & 2.1 & 0.92 & 0.76 & $\begin{array}{r}3.4 \\
(0.001)\end{array}$ \\
\hline IV & 2015 & $\begin{array}{r}25.03 \\
(0.85) \\
\end{array}$ & $\begin{array}{l}25.08 \\
(3.23) \\
\end{array}$ & 2.9 & 0.71 & 0.42 & $\begin{array}{r}6.1 \\
(0.01) \\
\end{array}$ \\
\hline $\mathrm{IV}^{2}$ & 2015 & $\begin{array}{r}7.82 \\
(0.41)\end{array}$ & $\begin{array}{r}8.81 \\
(0.78) \\
\end{array}$ & 1.9 & 0.89 & 0.65 & $\begin{array}{r}3.9 \\
(0.001)\end{array}$ \\
\hline V & 2015 & $\begin{array}{l}60.46 \\
(3.01) \\
\end{array}$ & $\begin{array}{r}22.45 \\
(4.81) \\
\end{array}$ & 7.0 & 0.54 & 0.15 & $\begin{array}{r}12.3 \\
(0.001) \\
\end{array}$ \\
\hline
\end{tabular}

\section{Models based on wind character- istics}

\section{Seed release}

The chrono-sequence of seed release from cones observed on the top of $A$. alba trees with daily records of wind speed is depicted in Fig. 4a. It suggests that the process is strongly intensified during windy weather. In addition, the continuance of the dispersal process after

\section{Table 2}

Parameters of the distributions of dispersal distances ${ }^{1}$ estimated from seed trap data

Note. ${ }^{1} p(r)=\sqrt{\frac{\lambda}{2 \pi r^{2}}} \exp \left[-\frac{\lambda(r-\mu)^{2}}{2 \mu^{2} r}\right] ;{ }^{2}$ secondary dispersal. 

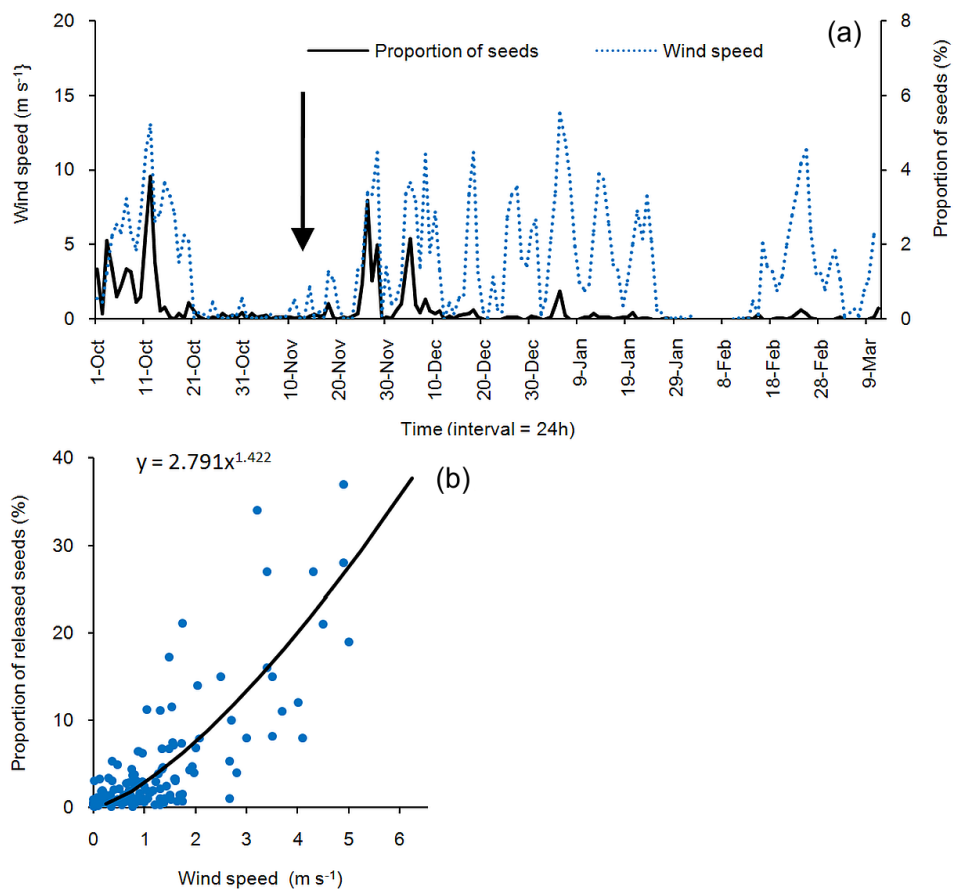

(b)

Figure 4 The chrono-sequence of the release of the seeds from the cones observed on the top of A. alba trees with daily records of wind speed (a) and the relationship between the average wind speed and the proportion of released seeds per $24 \mathrm{~h}$ (b). The arrow on panel denotes the date when the cones finally disintegrated, and all the seeds were released from the cones.

the breakup of cones confirms o ur observations that most of the seeds do not fall directly on the ground after they are released from the cones but remain trapped between the needles on the shoots of the maternal tree (or neighbouring conifer trees) and are successively subjected to secondary dispersal. The observations carried out in 2013 and 2015 in two $A$. alba stands indicated that between 24 and $66 \%$ (mean $=39 \%$ ) of the seeds undergo secondary dispersal from the shoots. The relationship between the daily average wind speed at tree top height and the proportion of seeds that landed on the ground per $24 \mathrm{~h}$ (released directly from the cones or from the shoots) is shown in Fig. 4b. This proportion varied between 0 and $37 \%$ $(100 \%=$ the total number of the seeds remaining in the crown zone) and amounted to $3.0 \%$ on average. prevailing wind direction.

Figure 5 displays the distances reached by the seeds depending on the wind speed on plots III, IV and V of contrasting density. The regression parameters for all the plots are listed in Table 3. In general, the linear regression models between wind speed at canopy height and distance reached by the seeds had weak to moderate prediction power, and the $\mathrm{R}^{2}$ coefficients varied between 0.11 and 0.47 . Interestingly, the intercept coefficients of the regression models attained values significantly higher than 0 , which denotes that even at low wind speeds measured at canopy height, the seeds landed several meters from the trunk bases. This was attributed to the fact that at low wind speeds the majority of the seeds were 

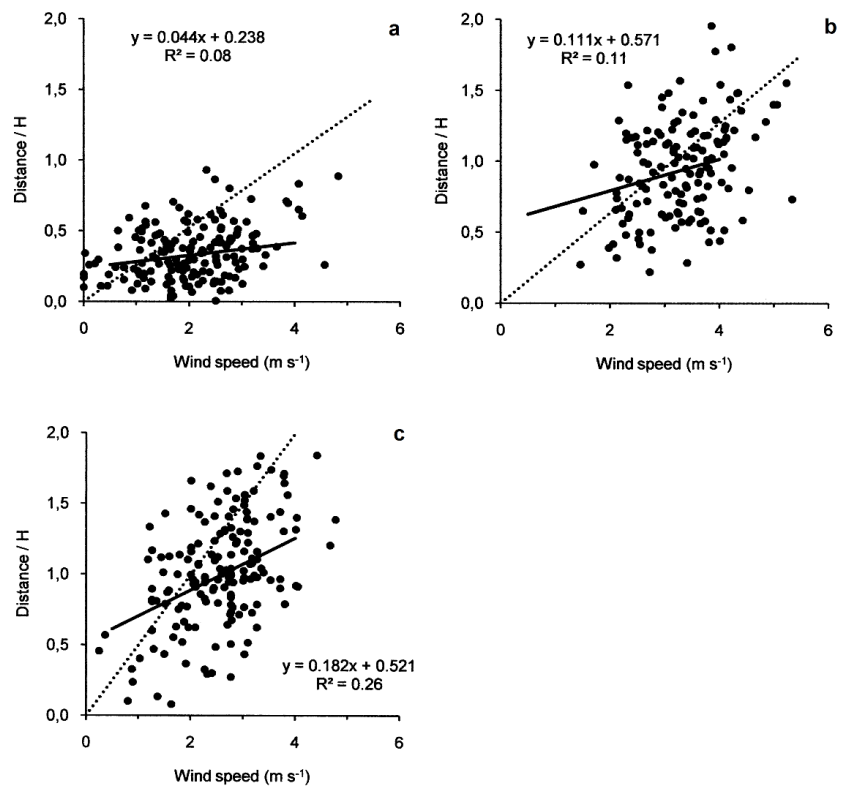

trapped in the crowns, and the constructed models considered only the seeds that successfully landed on the ground. The flight direction of the dropped seeds was up to $\pm 20^{\circ}$ across the wind direction measured at tree top height during seed flight.

Comparing models based on wind characteristics and seed trap experiments

In the seed-tracking experiment, between 69 and $82 \%$ of the seeds that successfully landed travelled shorter distances than predicted by the ballistic model based on wind speeds at canopy height (Fig. 5). Thus, the ballistic model based on wind speed at canopy height and the exponential wind profile strongly overestimated the flight distances of $A$. alba seeds. In comparison to the dispersal models based on the seed trap data, the seed shadows predicted by the empirical model were characterized by a lower proportion of seeds deposited

Table 3 Parameters of the linear regression models ( $Y=$ $\left.b_{0}+b_{1} \mathrm{X}\right)$ between wind speed at canopy height and relative distance reached by $A$. alba seeds on the study plots

\begin{tabular}{|c|c|c|c|c|c|c|}
\hline Plot & $\begin{array}{l}\text { Number } \\
\text { of seeds }\end{array}$ & $b_{0}(\mathrm{SE})$ & $b_{l}(\mathrm{SE})$ & SEE & $R^{2}$ & $\begin{array}{l}\text { Signifi- } \\
\text { cance } \\
\text { level }\end{array}$ \\
\hline I & 154 & $\begin{array}{l}0.219 \\
(0.034)\end{array}$ & $\begin{array}{l}0.057 \\
(0.013)\end{array}$ & 0.027 & 0.16 & 0.001 \\
\hline II & 145 & $\begin{array}{l}0.283 \\
(0.098)\end{array}$ & $\begin{array}{l}0.220 \\
(0.040)\end{array}$ & 0.025 & 0.47 & 0.001 \\
\hline III & 124 & $\begin{array}{l}0.238 \\
(0.094)\end{array}$ & $\begin{array}{l}0.044 \\
(0.039)\end{array}$ & 0.021 & 0.08 & 0.002 \\
\hline IV & 132 & $\begin{array}{l}0.571 \\
(0.113)\end{array}$ & $\begin{array}{l}0.111 \\
(0.053)\end{array}$ & 0.049 & 0.11 & 0.001 \\
\hline V & 153 & $\begin{array}{l}0.521 \\
(0.119)\end{array}$ & $\begin{array}{l}0.182 \\
(0.054)\end{array}$ & 0.059 & 0.26 & 0.001 \\
\hline
\end{tabular}

close to the source and median values strongly shifted towards larger distances (Fig. 3). These differences were well visible both in pure $A$. alba stands (plots III and IV) as well in the dense Norway spruce stand (plot I).

\section{Multiannual seed shadows versus par- entage assignment for seedlings}

In the single stands the number of positive seedling-seed tree assignments varied between 0 and 4 (1.1 on average) for the $95 \%$ confidence 1 evel a nd between 0 and 10 (5.1 on average) for the $80 \%$ level. Nonetheless, the distance distributions obtained for the two confidence 


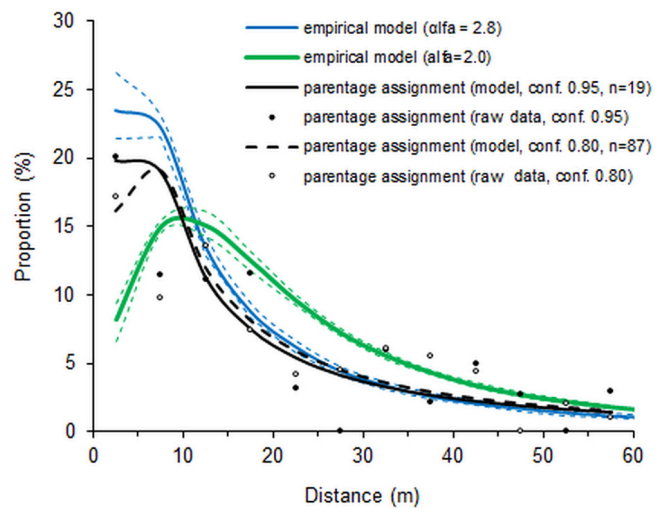

Figure 6 Comparison of multiannual seed shadows obtained from genetic parentage analysis and predicted by the empirical model for attenuation coefficients $\alpha=1$ and $\alpha=3$ (mean values and $95 \%$ prediction intervals).

levels were very concordant (Fig. 6). The inverse Gaussian distribution fitted to the genetic data $(95 \%$ confidence level for parentage assignment, $\mu=55.30$ and $\lambda=9.54$ ) yielded a median dispersal distance of $14.6 \mathrm{~m}$. For distances below $10 \mathrm{~m}$, the probability of finding an offspring of a given tree was between the boundary lines anticipated by the empirical dispersal model for the attenuation coefficients of 2.0 and 2.8 with median dispersal distances of 20.8 and 11.3, respectively (Fig. 6). Nonetheless, in the entire distance range, the gene shadow was closer to the line determined for more dense stands with an attenuation coefficient $\alpha=2.8$.

\section{Discussion}

Among the three methods used to estimate seed dispersal shadows, only the seed trapping experiments included the entire seed dispersal period and therefore seem to be the most reliable. The study encompassed a wide range of characteristics aimed at improving the performance of the models based on seed traps experiments. In addition to the customary po- sitioning of trees bearing cones, the number of cones on each tree was determined. In the calculations the asymmetry of the seed shadows resulting from sloping ground and the prevailing wind direction was taken into account, and correction was performed to account for seed flow from outside the sample plots. Despite these efforts, the statistical properties of the obtained models indicated only moderate goodness of fit, and the Pearson correlation coefficient values were between 0.11 and 0.50 for the entire seed fall season. Similar results were presented by De Andrés et al. (2014), who reported Pearson correlation coefficient values of only about 0.50 for the predicted versus observed A. alba seed density in 36 seed traps cumulated over 8 and 12 years in a dense mixed beech-fir stand and a mono-specific fir stand. However, for a comparable number of seed traps in an 80-year-old mixed conifer stand, Sagnard et al. (2007) obtained higher correlation coefficients ranging between 0.62 and 0.98 depending on the year and kernel function used. It may be hypothesised that the poor model fit obtained in our study was due to collisions with canopy elements and seed trapping occurring in dense canopies. These processes might significantly reduce the effect of wind speed on seed dispersal shadows (Bullock \& Moy 2004) and introduce a strong randomizing effect. Moreover, in stands with a high density of maternal trees and overlapping seed shadows, these effects may result in underestimation of dispersal distances as alien seeds falling in the proximity of a given tree may be misidentified as its own seeds. On the other hand, experiments involving solitary mother trees growing among trees of other species document a very specific case because such surroundings may shape peculiar wind profiles and result in different interactions with canopy elements dependent on species-specific crown architecture and stand density.

The distributions obtained from seed trapping data differed considerably, indicating that such results are valid only for the conditions 
under which the experiment was performed. In general, fat-tailed shadows were found in low-density stands. Therefore, differences between plots are partly attributable to variation in canopy closure. However, the contrasting wind conditions in 2013 and 2015 (with mean wind speeds of 3.7 and $1.5 \mathrm{~m} \mathrm{~s}^{-1}$, respectively) did not have an evident effect on distance distributions: significant shifts were found on plot II, but on plot I the seed shadows did not significantly differ between 2013 and 2015. One probable explanation for the lack of clear relationships is the dense canopy on plot II, which might more strongly limit seed movement.

The median dispersal distances ranging between 10.8 and $16.6 \mathrm{~m}$ estimated in the seed trapping experiment in plots I-IV with closed canopies were within the wide range of 6 and $22 \mathrm{~m}$ reported by other authors using seed trap methodology (Sagnard et al. 2007, Paluch 2011, Amm et al. 2012, De Andrés et al. 2014). The median dispersal distance estimated on plot $\mathrm{V}$ with the lowest stand density $(25.5 \mathrm{~m})$ was, however, closer to the value of $31.5 \mathrm{~m}$ reported by Cremer et al. (2012), who matched the microsatellite genotypes of maternal tissues of seeds with the genotypes of adult $A$. alba trees in a closed stand and an adjacent blowdown area. For comparison, in open spaces, at wind speeds of 1.7, 2.7 and $5.9 \mathrm{~m} \mathrm{~s}^{-1}$, seeds of $A$. alba Mill. released from a height of $14 \mathrm{~m}$ covered on average 26, 34 and $72 \mathrm{~m}$, respectively (Kohlermann 1950).

It is generally accepted that dispersal models based on exponential wind profiles are inherently inadequate for predicting dispersal over much longer distances, essentially because they do not incorporate fluctuations of vertical wind velocity, which is the main mechanism responsible for uplift and long-distance dispersal (Nathan et al. 2011). An important result of the present study was establishing that the direct application of exponential wind-profiles resulted in a considerably lower proportion of seeds being dispersed close to the seed source than that derived from the field measurements.
Our study shows that shorter flight distances can be attributed to frequent collisions with neighbouring trees, which leads to the disruption of seed autorotation and accelerated falling (Guries \& Nordheim 1984). In addition, a significant proportion of the seeds (depending on wind speed and local neighbour configuration ranging between 11 and 96\%) did not fall directly on the ground but were trapped between the needles in the tree crowns. Our field observations suggest that seed dispersal potential not only depends on the height difference between trees (Bohrer et al. 2008), but also on species-specific properties such as the density and adhesive properties of the leaves, canopy density, weather conditions causing dry or wet surfaces, and, in particular, wind conditions, which influence the degree of horizontal flight and the total distance travelled within the canopy zone. Also, a considerable proportion of the seeds underwent secondary release from the branches had damaged wings, suggesting that the empirical distances of secondary dispersal (between December and April) were shorter than those obtained for the entire seed fall season (between September and April) despite similar wind conditions (mean wind speed 1.3 and $1.5 \mathrm{~m} \mathrm{~s}^{-1}$, respectively). Moreover, about $20 \%$ of $A$. alba seeds fall to the ground before being separated from the scales of the the cone. Although this phenomenon was not directly quantified, it seems reasonable to expect that the distances covered by such "packets" are much shorter than those covered by freely released seeds.

We also investigated whether the empirical model coupled with multiannual wind characteristics provides a dispersal pattern concordant with the gene shadow obtained from parentage assignment between seedlings and overstorey trees. Although sample sizes were relatively small in the single stands (30 parent trees and 30 seedlings, five nSSRs), the analyses carried out in 16 stands yielded a sound sample of seedling-adult tree pairs. Nonetheless, the major limitation of the study remains 
that the effective dispersal kernel, which describes the spatial distribution of established seedlings relative to the seed source, may differ from the seed dispersal kernel describing the spatial distribution of seed deposition sites relative to the source (Amm et al. 2012). In the case of $A$. alba, among the main causes underlying this discrepancy are microsite filtering effects (Paluch et al. 2016) or inter-annual variation in the survival rate of seedlings (Paluch \& Stępniewska 2012). However, Klein et al. (2013) in a simulation study indicated that distance-dependent and environment-dependent mortality do not significantly influence the estimates of spatially explicit mating models that rely on the proportions in seed pools. Therefore, these proportions are insensitive to most forms of location-dependent mortality as long as the mortality is independent of genotype/source of origin. A second limitation that should be discussed is that since the nuclear DNA used in this study is biparentally inherited, it was impossible to distinguish between the seed donors (maternal parents) and pollen donors (paternal parents). In general, A. alba pollen, with a sedimentation velocity of ca. $0.12 \mathrm{~m} \mathrm{~s}^{-1}$ (Eisenhut 1961), is dispersed over longer distances than seeds, which fall at a velocity of ca. 1.25-1.30 $\mathrm{m} \mathrm{s}^{-1}$ (Kohlermann 1950, and data collected in this study). Thus, the dispersal pattern revealed in our parentage analysis reflects the effect of maternal rather than paternal sources.

For closed canopies, the results of the parentage analysis yielded comparable predictions to the empirical model based on direct measurements of distances reached by the seeds. Both methods produced similar distance distributions with the maximum proportion of seeds landing within $10 \mathrm{~m}$ of the source and similar median dispersal distances, which to some extent legitimises the predictions of the empirical model. A hypothetical explanation for the lower proportion of shorter distances anticipated by parentage assignment as compared to the seed trap experiments is that secondary dispersion during the winter season accounts for 34 a significant proportion of the seeds landing close to the source, and survival of the seeds experiencing harsh winter conditions may be lower than that of the seeds that have fallen in autumn, although this topic warrants further study.

\section{Conclusions}

The modelling indicated that, in addition to the customary location of maternal trees, the inclusion of variables such as the number of cones on individual trees, asymmetry of seed shadows and slope correction factors, results only in moderate goodness of fit of the models based on seed trapping data. The distances reached by single seeds at the same wind speed at canopy height strongly vary. The ballistic model based on wind speed at canopy height and the exponential wind profile overestimated the flight distances of $A$. alba seeds. Similarly, the empirical model that disregarded seeds trapped in the crowns of neighbouring conifer trees predicted a lower proportion of seeds landing close to the mother trees than the seed shadows derived from seed trap experiments during the entire seed fall season. The distances travelled by seeds at the secondary dispersion stage in winter were considerably shorter than those reached in autumn. The process of seed trapping in the canopy zone and collisions with canopy elements may considerably shorten the travelling distances of $A$. alba seeds. It remains an open question whether these results can be generalized for other wind-dispersed seeds with large wings. Further refinement of the mechanistic approach, which provides the most flexible framework for modelling the dispersal process of anemochoric species, requires further research focusing on the seed trapping effect, the secondary dispersion of trapped seeds and the inclusion of turbulence transfer characteristics. 


\section{Acknowledgments}

This work was supported by the National Science Centre, Poland - Grant no. 2012/07/B/ NZ9/00953. The authors also wish to thank Z. Kołodziej, PhD., and M. Marczyk for their help in collecting the field data.

\section{References}

Amm A., Pichot C., Dreyfus P., Davi H., Fady B., 2012. Improving the estimation of landscape scale seed dispersal by integrating seedling recruitment. Annals of Forest Science 69: 845-856. DOI: 10.1007/s13595012-0208-1

Augspurger C.K. 1986. Morphology and dispersal potential of wind dispersed diaspores of neotropical trees. American Journal of Botany 73: 353-363. DOI: 10.1002/j.1537-2197.1986.tb12048.x

Bohrer G., Katul G.G., Nathan R., Walko R.L., Avissar R., 2008. Effects of canopy heterogeneity, seed abscission, and inertia on wind-driven dispersal kernels of tree seeds. Journal of Ecology 96: 569-580. DOI: 10.1111/j.1365-2745.2008.01368.x

Bullock J.M., 2012. Plant dispersal and the velocity of climate change. In: Clobert J., Baguette M., Benton T.G., Bullock J.M. (eds.), Dispersal Ecology and Evolution, Oxford University Press, Oxford, pp. 366-380. DOI: 10.1093/acprof:oso/9780199608898.003.0029

Bullock J.M., Clarke R.T., 2000. Long distance seed dispersal by wind: measuring and modelling the tail of the curve. Oecologia 124: 506-521. DOI: $10.1007 /$ PL00008876

Bullock J.M., Moy I.L., 2004. Plants as seed traps: inter-specific interference with dispersal. Acta Oecologica 25: 35-41. DOI: 10.1016/j.actao.2003.10.005

Bullock J.M., Moy I.L., Coulson S.J., Clarke R.T., 2003. Habitat-specific dispersal: environmental effects on the mechanisms and patterns of seed movement in a grassland herb Rhinanthus minor. Ecography 26: 692-704. DOI: 10.1034/j.1600-0587.2003.03525.x

Burczyk J., Adams W.T., Birkes D.S., Chybicki I.J., 2006. Using genetic markers to directly estimate gene flow and reproductive success parameters in plants based on naturally regenerated seedlings. Genetics 173: 363-372. DOI: $10.1534 /$ genetics. 105.046805

Carlo T.A., Tewksbury J.J., del Río C.M., 2009. A new method to track seed dispersal and recruitment using $15 \mathrm{~N}$ isotope enrichment. Ecology 90: 3516-3525. DOI: 10.1890/08-1313.1

Chybicki I.J., Burczyk J., 2010. Realized gene flow within mixed stands of Quercus robur L. and Q. petraea (Matt.) L. revealed at the stage of naturally established seedling. Molecular Ecology 19: 2137-2151. DOI: 10.1111/j.1365-294X.2010.04632.x

Cionco R.M., 1965. A mathematical mod- el for air flow in a vegetative canopy. Journal of Applied Meteorology 4: 517-522. DOI: 10.1175/1520-0450(1965)004<0517:AMMFAF $>2.0$. $\mathrm{CO} ; 2$

Cremer E., Ziegenhagen B., Schulerowitz K., Mengel K., Donges K., Bialozyt R., Hussendörfer E., Liepelt S., 2012. Local seed dispersal in European silver fir (Abies alba Mill.): lessons learned from a seed trap experiment. Trees 26: 987-996. DOI: 10.1007/s00468-0120676-9

Cremer E., Liepelt S., Sebastiani F., Buonamici A., Michalczyk I.M., Ziegenhagen B., Vendramin G.G., 2006. Identification and characterization of nuclear microsatellite loci in Abies alba Mill. Molecular Ecology Notes 6: 374-376. DOI: 10.1111/j.1471-8286.2005.01238.x

De Andrés E.G., Camarero J.J., Martínez I., Coll L., 2014. Uncoupled spatio-temporal patterns of seed dispersal and regeneration in Pyrenean silver fir populations. Forest Ecology and Management 319: 18-28. DOI: 10.1016/j.foreco.2014.01.050

Eisenhut G., 1961. Untersuchungen über die Morphologie und Ökologie der Pollenkörner heimischer und fremdländischer Waldbäume [Studies on the morphology and ecology of native pollen grains of forest trees]. Forstwissenschaftliche Forschungen 15: 1-68.

Goudet J., 2002. FSTAT, a program to estimate and test gene diversities and fixation indices (Version 2.9.3.2). Web: http://www.unil.ch/izea/softwares/fstat.html. Accessed: 25 June 2016.

Greene D.F., Calogeropoulos C., 2002. Measuring and modelling seed dispersal of terrestrial plants. In: Bullock J.M., Kenward R.E., Hails R.S. (eds.), Dispersal ecology, Blackwell Science, Oxford, pp. 2-21.

Greene D.F., Johnson E.A., 1997. Secondary dispersal of tree seeds on snow. Journal of Ecology 85: 329-340. DOI: $10.2307 / 2960505$

Greene D.F., Canham C.D., Coates K.D., Lepage P.T., 2004. An evaluation of alternative dispersal functions for trees. Journal of Ecology 92: 758-766. DOI: 10.1111/j.0022-0477.2004.00921.x

Greene D.F., 2005. The role of abscission in long-distance seed dispersal by the wind. Ecology 86: 3105-3110. DOI: $10.1890 / 04-1430$

Grivet D., Smouse P.E., Sork V.L., 2005. A novel approach to an old problem: tracking dispersed seeds. Molecular Ecology 14: 3585-3595. DOI: 10.1111/j.1365294X.2005.02680.X

Guries R.P., Nordheim E.V., 1984. Flight characteristics and dispersal potential of maple samaras. Forest Science 30: 434-440.

Hamrick J.L., Trapnell D.W., 2011. Using population genetic analyses to understand seed dispersal patterns. Acta Oecologica 37: 641-649. DOI: 10.1016/j. actao.2011.05.008

Higgins S.I., Nathan R., Cain M.L., 2003. Are long-distance dispersal events in plants usually caused by nonstandard means of dispersal? Ecology 84: 1945-1956. DOI: $10.1890 / 01-0616$ 
Higgins S.I., Richardson D.M., 1999. Predicting plant migration rates in a changing world: the role of long-distance dispersal. The American Naturalist 153: 464-475. DOI: $10.1086 / 303193$

Horvitz C.C., Schemske D.W., 1994. Effects of dispersers, gaps, and predators on dormancy and seedling emergence in a tropical herb. Ecology 75: 1949-1958. DOI: $10.2307 / 1941599$

Jones A.G., Small C.M., Paczolt K.A., Ratterman N.L., 2010. A practical guide to methods of parentage analysis. Molecular Ecology Resources 10: 6-30. DOI: 10.1111/j.1755-0998.2009.02778.x

Kaimal J.C., Finnigan J.J., 1994. Atmospheric boundary layer flows: their structure and measurement. Oxford University Press, New York, 289 p.

Kalinowski S.T., Taper M.L., Marshall T.C., 2007. Revising how the computer program CERVUS accommodates genotyping error increases success in paternity assignment. Molecular Ecology 6: 1099-1106. DOI: 10.1111/j.1365-294X.2007.03089.x

Klein E.K., Bontemps A., Oddou-Muratorio S., 2013. Seed dispersal kernels estimated from genotypes of established seedlings: does density-dependent mortality matter? Methods in Ecology and Evolution 4: 10591069. DOI: $10.1111 / 2041-210 X .12110$

Kohlermann L., 1950. Untersuchungen über die Windverbreitung der Früchte und Samen Mitteleuropäischer Waldbäume [Studies on the wind spread of fruits and seeds in Central European forest trees]. Forstwissenschaftliches Centralblatt 69: 606-624. DOI: 10.1007/ BF01815738

Kuparinen A., Katul G., Nathan R., Schurr F.M., 2009. Increases in air temperature can promote wind-driven dispersal and spread of plants. Proceedings of the Royal Society B: Biological Sciences 276: 3081-3087. DOI: 10.1098/rspb.2009.0693

Kuparinen A., 2006. Mechanistic models for wind dispersal. Trends in Plant Science 11: 296-301. DOI: 10.1016/j.tplants.2006.04.006

Meagher T.R., Thompson E., 1986. The relationship between single parent and parent pair genetic likelihoods in genealogy reconstruction. Theoretical Population Biology 29: 87-106. DOI: 10.1016/0040-5809(86)900067

Moran E.V., Clark J.S., 2011. Estimating seed and pollen movement in a monoecious plant: a hierarchical Bayesian approach integrating genetic and ecological data. Molecular Ecology 20: 1248-1262. DOI: 10.1111/j.1365-294X.2011.05019.x

Nathan R., Katul G.G., Horn H.S., Thomas S.M., Oren R., Avissar R., Pacala S.W., Levin S.A., 2002. Mechanisms of long-distance dispersal of seeds by wind. Nature 418 : 409-413. DOI: 10.1038 /nature00844

Nathan R, Perry G, Cronin JT, Strand AE, Cain ML (2003) Methods for estimating long-distance dispersal. Oikos 103: 261-273. DOI: 10.1034/j.1600-0706.2003.12146.x

Nathan R., Katul G.G., Bohrer G., Kuparinen A., Soons M.B., Thompson S.E., Trakhtenbrot A., Horn S., 2011.
Mechanistic models of seed dispersal by wind. Theoretical Ecology 4: 113-132. DOI: 10.1007/s12080-0110115-3

Oddou-Muratorio S., Klein E., 2008 Comparing direct vs. indirect estimates of gene flow within a population of a scattered tree species. Molecular Ecology 17: 27432754. DOI: 10.1111/j.1365-294X.2008.03783.x

Paluch J., Stępniewska H., 2012. Effect of microsites on the survival, density, and ectomycorrhizal status of shade-tolerant Abies alba regeneration attacked by fungal pathogens. Canadian Journal of Forest Research 42: 720-732. DOI: 10.1139/x2012-015

Paluch J., 2011. Ground seed density patterns under conditions of strongly overlapping seed shadows in Abies alba Mill. stands. European Journal of Forest Research 130: 1009-1022. DOI: 10.1007/s10342-011-0486-4

Paluch J., Kołodziej Z., Skrzyszewski J., Bartkowicz L., Gruba P., 2016. Regeneration patterns of the late-successional Abies alba Mill.: Inhibition in monospecific stands and colonization in mixed stands. Annals of Forest Science 73: 1015-1024. DOI: 10.1007/s13595016-0573-2

Paluch J., Zarek M., Kempf M., 2019. The effect of population density on gene flow between adult trees and the seedling bank in Abies alba Mill. European Journal of Forest Research 138: 203-217. DOI: 10.1007/s10342019-01162-w

Paszyński J., Niedzwiedź T., 1999. Klimat [Climate]. In: Starkel L. (ed.), Geografia Polski. Środowisko przyrodnicze, PWN, Warszawa, pp. 288-343.

Pielaat A., Lewis M.A., Lele S., de Camino Beck T., 2006. Sequential sampling designs for catching the tail of dispersal kernels. Ecological Modeling 190: 205-222. DOI: 10.1016/j.ecolmodel.2005.02.023

Raybould A.F., Clarke R.T., Bond J.M., Welters R.E., Gliddon C., 2002. Inferring patterns of dispersal from allele frequency data. In: Bullock J.M., Kenward R.E., Hails R. (eds.), Dispersal ecology, Blackwell Science, Oxford, pp. 89-111.

Rohmeder E., 1972. Das Saatgut in der Forstwirtschaft [The seeds in forestry]. Parey, Hamburg, 273 p.

Sagnard F., Pichot C., Dreyfus P., Jordano P., Fady B., 2007. Modelling seed dispersal to predict seedling recruitment: recolonization dynamics in a plantation forest. Ecological Modeling 203: 464-474. DOI: 10.1016/j. ecolmodel.2006.12.008

Sagnard F., Oddou-Muratorio S., Pichot C., Vendramin G.G., Fady B., 2011. Effects of seed dispersal, adult tree and seedling density on the spatial genetic structure of regeneration at fine temporal and spatial scales. Tree Genetics \& Genomes 7: 37-48. DOI: 10.1007/s11295010-0313-y

Sánchez J.M.C., Greene D.F., Quesada M., 2011. A field test of inverse modeling of seed dispersal. American Journal of Botany 98: 698-703. DOI: 10.3732/ ajb.1000152

Schippers P., Jongejans E., 2005. Release thresholds strongly determine the range of seed dispersal by wind. 
Ecological Modeling 185: 93-103. DOI: 10.1016/j. ies alba Mill., PWN, Warsaw, pp. 175-265.

ecolmodel.2004.11.018

Schurr F.M., Bond W.J., Midgley G.F., Higgins 2005. A mechanistic model for secondary seed dispersal by wind and its experimental validation. Journal of Ecology 93: 1017-1028. DOI: 10.1111/j.13652745.2005.01018.x

Schütt P., 1991. Tannenarten Europas und Kleinasiens [Fir species in Europe and Asia Minor]. Verlag Birkhäuser, Basel, 136 p. DOI: 10.1007/978-3-0348-7689-6

Skarpaas O., Shea K., Bullock J.M., 2005. Optimizing dispersal study design by Monte Carlo simulation. Journal of Applied Ecology 42: 731-739. DOI: 10.1111/j.13652664.2005.01056.x

Skrzypczyńska M., Sudoł-Kornalewicz A., Kornalewicz A., Biczak J., Rodkiewicz S., 2001. Cono-and seminiphagous insects of Abies alba Mill. in the Gorce National Park in Poland during 1996-1998. Journal of Pest Science 74: 138-143. DOI: 10.1046/j.14390280.2001.01027.x

Snyder R.E., Chesson P., 2004. How the spatial scales of dispersal, competition, and environmental heterogeneity interact to affect co-existence. The American Naturalist 164: 633-650. DOI: 10.1086/424969

Suszka B., 1983. Rozmnażanie generatywne [Generative propagation]. In Białobok S. (ed.), Jodła pospolita $\mathrm{Ab}$ -
Tackenberg O., 2003. Modeling long distance

S.I., dispersal of plant diaspores by wind. Ecological Monographs 73: 173-189. DOI: 10.1890/0012-9615(2003)073[0173:MLDOPD]2.0. $\mathrm{CO} ; 2$

Trepińska J., Kowanetz K., 2000. Dependence of wind direction and speed on the orography in the western part of the Beskidy Mountains. Prace Geograficzne 105: 165-181.

Turner M.G., Turner D.M., Romme W.H., Tinker D.B., 2007. Cone production in young post-fire Pinus contorta stands in Greater Yellowstone (USA). Forest Ecology and Management 242: 119-126. DOI: 10.1016/j. foreco.2006.12.032

Vornam B., Decarli N., Gailing O., 2004. Spatial distribution of genetic variation in a natural beech stand (Fagus sylvatica L.) based on microsatellite markers. Conservation Genetics 5: 561-570. DOI: 10.1023/B:COGE.0000041025.82917.ac

Westcott D.A., Bentrupperbaumer J., Bradford M.G., McKeown A., 2005. Incorporating patterns of disperser behaviour into models of seed dispersal and its effects on estimated dispersal curves. Oecologia 146: 57-67. DOI: $10.1007 / \mathrm{s} 00442-005-0178-1$ 
